\title{
ODPOWIEDZIALNOŚĆ CYWILNA ZARZĄDZAJĄCEGO PORTFELEM INSTRUMENTÓW FINANSOWYCH
}

\section{WSTĘP}

Przedmiotem niniejszej publikacji jest zagadnienie odpowiedzialności cywilnej zarządzajacego portfelem instrumentów finansowych $\mathrm{w}$ prawie polskim. Wraz z transformacją ustroju gospodarczego i rozwojem rynku kapitałowego w Polsce znaczenie instytucji zarządzania portfelem instrumentów finansowych sukcesywnie rośnie, choć pozostaje ono niewspółmiernie niższe w porównaniu z rolą instytucji zbiorowego zarządzania inwestycjami w postaci funduszy inwestycyjnych ${ }^{1}$. W praktyce jest to raczej instytucja wykorzystywana przez zamożniejszych klientów ${ }^{2}$. Pomimo rosnącego znaczenia praktycznego omawianej instytucji pozostaje ona poza głównym nurtem zainteresowań literatury prawniczej oraz orzecznictwa sądowego ${ }^{3}$.

$\mathrm{Z}$ zarządzaniem portfelem instrumentów finansowych, będącym jedną z usług maklerskich (inwestycyjnych) sensu stricto, wiąże się dla klienta ryzyko kosztów agencyjnych wynikających z dużego zakresu dyskrecjonalności zarządzającej firmy inwestycyjnej w podejmowaniu i wykonywaniu decyzji inwestycyjnych na rachunek klienta. Instytucja umowy, będąca typowym instrumentem ograniczania kosztów agencyjnych, nie jest tutaj wystarczajacym środkiem ochrony klienta $\mathrm{z}$ uwagi na trudności z wykryciem ewentualnego nienależytego jej wykonywania ${ }^{4}$. Prawo europejskie, współkształtujące w tym zakresie polski system prawny, poddaje więc analizowaną usługę maklerska wielopłaszczyznowej regulacji ${ }^{5}$. W konsekwencji świadczenie usługi zarządzania portfelem podlega swoistemu dualizmowi normatywnemu. Po pierwsze, usługi te wykonywane sa na podstawie umów zawieranych z inwestorami. Po drugie, świadczenie usług maklerskich jest przedmiotem rozbudowanych regulacji publicznoprawnych wynikających z dyrektywy MiFID I ${ }^{6}$, których

${ }^{1}$ Por. S. Buczek (red.), Asset Management - zarzqdzanie aktywami w Polsce, Warszawa 2006, s. 9; A. W. Kawecki, w: D. Busch, D. A. DeMott, Liability of Asset Managers, Oxford 2012, s. 251 i n., s. 262.

${ }^{2}$ Por. S. Buczek (red.), op. cit., s. 9 i n.

${ }^{3}$ Zjawisko to nie jest jednak wyłącznie polską specyfiką: D. A. DeMott, Regulatory techniques and liability regimes for asset managers, „Capital Markets Law Journal” 7(4), 2012, s. 423.

${ }^{4}$ Ibidem, s. 424.

${ }^{5}$ Ibidem.

${ }^{6}$ Dyrektywa 2004/39/WE Parlamentu Europejskiego i Rady z 21 kwietnia 2004 r. w sprawie rynków instrumentów finansowych zmieniającej dyrektywę Rady 85/611/EWG i 93/6/EWG i dy- 
celem jest ochrona inwestorów. Wzajemne relacje pomiędzy tymi dwoma płaszczyznami normatywnymi sa jednym z centralnych zagadnień niniejszego opracowania.

Celem obu dyrektyw MiFID jest harmonizacja zasad funkcjonowania firm inwestycyjnych świadczących usługi maklerskie w Europie oraz ochrona inwestorów korzystających z usług maklerskich ${ }^{7}$. Jakkolwiek odpowiedzialność cywilna firm inwestycyjnych świadczących usługi maklerskie należy do szeroko rozumianej problematyki ochrony inwestorów korzystających z tych usług, to jednak zagadnienie to pozostawiono poszczególnym państwom członkowskim do unormowania. Rozbieżności w tym zakresie pomiędzy poszczególnymi państwami niewątpliwie zmniejszają harmonizacyjny skutek obu dyrektyw ${ }^{8}$. Zadaniem niniejszego artykułu jest określenie podstawowych zasad odpowiedzialności cywilnej zarządzających portfelem instrumentów finansowych w prawie polskim oraz sformułowanie propozycji rozwiązania najczęściej pojawiających się problemów w tym zakresie.

\section{CHARAKTER PRAWNY UMOWY O ZARZĄDZANIE PORTFELEM}

Na mocy umowy o zarządzanie portfelem instrumentów finansowych firma inwestycyjna zobowiązuje się do zarządzania instrumentami finansowymi i środkami finansowymi klienta dla osiagnięcia określonego w umowie celu, którym w praktyce jest zysk. Firma inwestycyjna zarządza portfelem klienta na podstawie stosunkowo szerokiego pełnomocnictwa upoważniającego ją do nabywania lub zbywania instrumentów finansowych w imieniu i na rachunek klienta, choć spotyka się niekiedy także transakcje dokonywane przez firmę inwestycyjna w imieniu własnym, lecz na rachunek klienta ${ }^{9}$. Zobowiązanie do zarządzania portfelem klienta oznacza zatem obowiązek podejmowania i wykonywania decyzji inwestycyjnych w odniesieniu do należącego do klienta portfela instrumentów finansowych celem osiagania zysku ${ }^{10}$.

W ramach realizacji swoich obowiązków zarządczych firma inwestycyjna podejmuje decyzje inwestycyjne na rachunek klienta zasadniczo samodzielnie, w oparciu o swoją profesjonalną wiedzę i doświadczenie, dysponując $\mathrm{w}$ tym zakresie znaczną swobodą. Swoboda firmy inwestycyjnej jest z reguły ogra-

rektywę 2000/12/WE Parlamentu Europejskiego i Rady oraz uchylającej dyrektywę Rady 93/22/EWG, Dz. Urz. UE L 145 z 30 kwietnia 2004 r., s. 1. Od 3 stycznia 2018 r. powinny być one zastapione przez regulacje wynikające z jej zmodyfikowanej wersji - dyrektywy Parlamentu Europejskiego i Rady 2014/65/UE z 15 maja 2014 r. w sprawie rynków instrumentów finansowych oraz zmieniającej dyrektywę 2002/92/WE i dyrektywę 2011/61/UE, Dz. Urz. UE L 173 z 12 czerwca 2014 r., s. 349 (dalej jako: MiFID II).

${ }^{7}$ Zob. N. Moloney, EU Securities and Financial Markets Regulation, Oxford 2014, s. 340.

${ }^{8}$ D. Busch, Why MiFID matters to private law - the example of MiFID's impact on an asset manager's civil liability, „Capital Markets Law Journal” 7(4), 2012, s. 388 i n.

${ }^{9}$ D. Busch, op. cit., s. 388 i n.

${ }^{10}$ Ibidem. 
niczona przez uzgodnioną pomiędzy stronami politykę zarządzania portfelem instrumentów finansowych klienta ${ }^{11}$.

W prawie polskim podstawowe unormowania dotyczące umowy o zarządzanie portfelem instrumentów finansowych można odnaleźć w art. 75 u.o.i.f. oraz wydanym na jej podstawie rozporządzeniu Rady Ministrów w sprawie trybu i warunków postępowania firm inwestycyjnych, banków, o których mowa w art. 70 ust. 2 ustawy o obrocie instrumentami finansowymi, oraz banków powierniczych (dalej jako: r.t.w.p.), transponujacych do polskiego porządku prawnego unormowania dyrektywy MiFID $\mathrm{I}^{12}$.

Zobowiązanie firmy inwestycyjnej jest co do zasady zobowiązaniem starannego działania - powinna ona podjąć działania mające na celu maksymalizację stopy zwrotu (rentowności) z portfela. Za taka kwalifikacją omawianej umowy przemawia fakt, że wyniki zarządzania portfelem instrumentów finansowych z reguły nie zależą wyłącznie od działań firmy inwestycyjnej, lecz wpływają na nie także czynniki zewnętrzne, np. otoczenie makroekonomiczne, trendy rynkowe, które mogą powodować spadek wartości określonej klasy instrumentów finansowych ${ }^{13}$.

Majac na uwadze treść art. 75 ust. 1 u.o.i.f., należy przyjąć, że firma inwestycyjna może też wykonywać zlecenia nabycia i zbycia instrumentów finansowych na rachunek klienta, ale w imieniu własnym. Innymi słowy, pojęcie zarządzania portfelem instrumentów finansowych na gruncie art. 75 ust. 1 u.o.i.f. obejmuje także sytuację, gdy firma inwestycyjna jako swoisty powiernik zarządza w interesie swojego klienta (na jego rachunek) instrumentami finansowymi, które formalnie należą do niej.

\section{PUBLICZNOPRAWNE REGULACJE ZARZĄDZANIA INSTRUMENTAMI FINANSOWYMI}

\section{Wprowadzenie}

Zarówno dyrektywa MiFID I, jak i MiFID II poddają zarządzanie portfelem instrumentów finansowych ogólnym wymogom przewidzianym dla prowadzenia działalności maklerskiej. Implementujące dyrektywę MiFID I polskie przepisy r.t.w.p. przewidują szereg wymogów wobec firm inwestycyjnych świadczących usługi zarządzania portfelem instrumentów finansowych. Dotyczą one w szczególności konieczności uzyskania zezwolenia organu nadzo-

11 Ibidem. Na temat charakteru prawnego umowy o zarządzanie portfelem w prawie polskim - zob. szerzej: A. Chłopecki, w: A. Szumański (red.), System prawa prywatnego, t. 19: Prawo papierów wartościowych, Warszawa 2006, s. 972 i n.; podobnie P. Zapadka, w: M. Wierzbowski, L. Sobolewski, P. Wajda, Prawo rynku kapitałowego. Komentarz, wyd. 2, Warszawa 2014, s. 905.

12 Rozporządzenie Ministra Finansów z 24 września 2012 r. w sprawie trybu i warunków postępowania firm inwestycyjnych, banków, o których mowa w art. 70 ust. 2 ustawy o obrocie instrumentami finansowymi, oraz banków powierniczych, t.jedn.: Dz. U. 2015, poz. 878 ze zm.

${ }_{13}$ Por. ibidem, s. 972 i n.; podobnie: P. Zapadka, w: M. Wierzbowski, L. Sobolewski, P. Wajda (red.), op. cit., s. 905-906. 
ru na prowadzenie takiej działalności. Samo prowadzenie zarządzania poddane zostało ogólnym unormowaniom dotyczacym sposobu świadczenia usług maklerskich (conduct of business rules), a więc obowiązkowi lojalności firmy inwestycyjnej wobec swojego klienta, przed- oraz pokontraktowym obowiązkom informacyjnym firmy inwestycyjnej oraz przedkontraktowemu obowiązkowi poznania swojego klienta celem ustalenia odpowiedniości danej usługi (zob. art. 19 MiFID I oraz art. 24-25 MiFID II). W tym ostatnim zakresie zarządzanie portfelem poddane zostało podwyższonym obowiązkom eksploracyjnym firmy inwestycyjnej, mającym na celu pozyskanie wiedzy na temat celów inwestycyjnych klienta, jego sytuacji finansowej i skłonności do ryzyka oraz doświadczenia inwestycyjnego (§ 16 ust. 1 i 5 r.t.w.p.).

\section{Publicznoprawny charakter norm implementujących MiFID}

Dominujacy pogląd doktryny większości krajów europejskich przyjmuje, że unormowania wynikajace z dyrektywy MiFID maja co do zasady charakter publicznoprawny. Nakładają one na firmy inwestycyjne obowiązki, do których egzekucji powołane są przede wszystkim organy nadzoru (por. np. art. 167 u.o.i.f. ${ }^{14}$. Odnotować jednak należy, że w prawie włoskim przyjmuje się podwójna naturę przynajmniej niektórych spośród tych unormowań - a więc zarówno publiczno- jak i prywatnoprawna ${ }^{15}$. Pogląd ten podzielany jest także przez niektórych przedstawicieli doktryny niemieckiej ${ }^{16}$.

Za publicznoprawnym charakterem większości norm wynikających z dyrektywy MiFID na gruncie prawa polskiego przemawia przede wszystkim to, że znajdują one zastosowanie niezależnie od wiążącej klienta z firmą inwestycyjną umowy. Co więcej, najczęściej nie mają one na celu wyłącznie ochrony interesu określonego klienta, lecz także szerszy interes publiczny, jak budowanie zaufania społecznego wobec instytucji rynku kapitałowego oraz efektywność funkcjonowania rynku kapitałowego. Mimo to - jak się wydaje - nie należy apriorycznie wykluczać podwójnej (publiczno-prywatnej) natury określonego unormowania implementującego dyrektywy MiFID. Za każdym razem decydować o tym powinna wykładnia odpowiednich przepisów prawa krajowego kształtujących określoną instytucję.

Publicznoprawny charakter unormowań dyrektywy MiFID nie zmienia jednak faktu, że część z nich dotyczy bezpośrednio sposobu świadczenia usług

${ }_{14}$ Zob. np. I. Koller, w: H. D. Assmann, U. H. Schneider (Hrsg.), Wertpapierhandelsgesetz, Köln 2012, s. 1361 i n.; N. Moloney, EU Securities..., s. 601; Paradoksalnie treść publicznoprawnych norm dyrektywy MiFID dotyczących świadczenia usług inwestycyjnych ma swoje korzenie w prawie prywatnym poszczególnych państw członkowskich (głównie RFN i Holandii), a precyzyjniej rzecz biorąc, w orzecznictwie dotyczącym kontraktowych obowiązków firmy inwestycyjnej wobec swoich klientów - zob. O. O. Cherednychenko, Full harmonization of retail financial services contract law in Europe, w: S. Grundmann, Y. M. Ataner (eds.), Financial Services, Financial Crisis and General European Contract Law.

${ }^{15}$ D. Busch, D. A. DeMott, op. cit., s. 538.

16 T. M. J. Möllers, w: H. Hirte, T. M. J. Möllers (red.), Kölner Kommentar zum WpHG, Köln-Berlin-München 2007, s. 1276; zob. także: M. Casper, Ch. Altgen, w: D. Busch, D. A. DeMott, op. cit., s. 101 wraz ze wskazaną tam literatura. 
maklerskich (inwestycyjnych) przez firmy inwestycyjne (conduct of business rules), a więc relacji pomiędzy usługodawca a jego klientem, która jednocześnie jest przedmiotem kontraktowych stosunków cywilnoprawnych. Pociaga to za sobą cały szereg szczegółowych problemów prawnych zwiąanych ze wzajemnymi relacjami tych dwóch odmiennych płaszczyzn normatywnych.

W literaturze nie budzi większej wątpliwości, że publicznoprawne unormowania dotyczące świadczenia usług maklerskich do pewnego stopnia wpływają na wykładnię przepisów prawa prywatnego oraz treść obowiązków kontraktowych podmiotów świadczacych usługi maklerskie. W doktrynie niemieckiej przyjmuje się, że normy publicznoprawne swoiście „promieniuja” (tzw. Austrahlungseffekt) na stosunki cywilnoprawne ${ }^{17}$. Niekiedy podnosi się nawet, że prawodawca krajowy nie może całkowicie wyłączyć wpływu dyrektywy MiFID na stosunki cywilnoprawne, gdyż podważałoby to możliwość osiagnięcia niektórych celów tej dyrektywy, do których należy ochrona inwestorów ${ }^{18}$.

W odniesieniu do prawa polskiego należy zauważyć, że normy wyrażone w dyrektywie MiFID oraz przepisach implementujących tę dyrektywę moga wpływać na wykładnię umów, których przedmiotem jest świadczenie usług maklerskich (art. 65 k.c.), a także stosownych przepisów Kodeksu cywilnego dotyczących sposobu wykonywania zobowiązań wynikających z tych umów (art. 354 oraz art. 355 k.c.). W tym ostatnim przypadku przepisy publicznoprawne mogą stanowić wskazówkę przy interpretacji pojęcia „cel społeczno-gospodarczego zobowiązania” firmy inwestycyjnej wynikającego z umowy o świadczenie usług maklerskich, a także właściwych w tym zakresie zasad współżycia społecznego oraz ustalonych zwyczajów (art. 354 k.c.) ${ }^{19}$. Przepis art. 354 k.c. w zw. z art. 83a ust. 3 u.o.i.f. stanowi bowiem podstawę normatywną obowiązku firmy inwestycyjnej do działania w interesie swojego klienta i związanego z tym obowiązku lojalności. Artykuł 83a ust. 3 u.o.i.f. stanowi bowiem, że firma inwestycyjna jest obowiązana, świadcząc usługę maklerska, brać pod uwagę najlepiej pojęty interes klienta.

Przyjąc więc należy, że sądy orzekające w sprawach dotyczących nienależytego wykonania zobowiązań umownych przez podmioty świadczące usługi maklerskie powinny brać pod uwagę szczegółową treść obowiązków tych podmiotów wynikających z regulacji publicznoprawnych. Dotyczy to np. obowiązku wykonywania zleceń na warunkach najbardziej korzystnych dla klienta (zob. $\$ 47$ i n. r.t.w.p.).

Dużo bardziej kontrowersyjnym zagadnieniem jest to, czy sądy cywilne mogą dokonywać wykładni ciążącego na firmie inwestycyjnej kontraktowego obowiązu działania w interesie klienta w sposób bardziej restryktywny, aniżeli wynika to z dyrektyw MiFID, a także czy dyrektywy MiFID ograniczaja swobodę polskiego prawodawcy lub polskich sądów w zakresie kształtowania

17 Zob. I. Koller, w: H. D. Assmann, U. H. Schneider, op. cit., s. 1361; M. Casper, Ch. Altgen, w: D. Busch, D. A. DeMott, op. cit., s. 105 wraz ze wskazaną tam literatura; zob. także M. Tison, The civil law effects of MiFID in a comparative law perspective, w: Festschrift für Klaus J. Hopt. Unternehmen, Markt ung Verantwortung, Bd. 2, Berlin-New York 2010, s. 2621 i n.

18 M. Tison, op. cit., s. 2622 i n.

19 Tak też: A. W. Kawecki, w: D. Busch, D. A. DeMott, op. cit., s. 262. 
norm prawa prywatnego, określających treść stosunków zobowiązaniowych pomiędzy podmiotami świadczaccymi usługi maklerskie a ich klientami.

Badania prawnoporównawcze pozwalają wyróżnić dwa stanowiska. Pierwsze zakłada, że skoro dyrektywa MiFID nie ingeruje w treść prawa umów krajów członkowskich, ustanawiając wyłącznie normy o charakterze publicznoprawnym, oznacza to, że prawodawca krajowy oraz organy sądownicze dysponuja odpowiednio swobodą w zakresie stanowienia i wykładni norm prawa prywatnego ${ }^{20}$. W świetle tego stanowiska publicznoprawny obowiązek pieczy i lojalności firmy inwestycyjnej (duty of care and loyalty) stanowi swoistą wskazówkę interpretacyjną dla sądów cywilnych rozstrzygających zagadnienie szczegółowej treści cywilnoprawnego obowiązku pieczy i lojalności, natomiast nie ogranicza sądów cywilnych w tym zakresie ${ }^{21}$.

W świetle drugiego stanowiska swoboda poszczególnych państw członkowskich w zakresie kształtowania i interpretacji norm prawa prywatnego dotyczących świadczenia usług maklerskich (inwestycyjnych) jest trudna do pogodzenia z maksymalnym standardem harmonizacji wprowadzonym przez dyrektywę MiFID oraz jej celami. W literaturze przedmiotu przeważa bowiem pogląd, że normy dyrektywy MiFID mają charakter regulacji maksymalnej, na co wskazuje szczegółowy charakter tych unormowań i ich cel - a mianowicie integracja europejskiego rynku kapitałowego i ułatwienie transgranicznej działalności firm inwestycyjnych ${ }^{22}$. Oznaczałoby to, że państwa członkowskie nie mogą ustanawiać surowszych regulacji dotyczących sposobu świadczenia usług maklerskich przez firmy inwestycyjne, gdyż utrudniałoby to transgraniczne świadczenie tych usług w ramach wspólnego rynku $\mathrm{UE}^{23}$. Odmienne regulacje cywilnoprawne dotyczące umów stanowiłyby przeszkodę dla transgranicznego świadczenia usług maklerskich, gdyż firma inwestycyjna musiałaby w każdym państwie członkowskim dostosowywać swoją działalność do bezwzględnie obowiązujących norm prawa prywatnego kształtujących treść stosunków kontraktowych ${ }^{24}$.

Odnosząc się do tej dyskusji, opowiadam się za względną autonomią prawa prywatnego krajów członkowskich. Wydaje się, że prawodawca krajowy może kształtować normy prawa prywatnego, które nakładają na podmioty świadczace usługi maklerskie dodatkowe lub dalej idące obowiązki, aniżeli te wynikające z dyrektywy MiFID. Podobnie też sądy cywilne państw członkowskich mogą dokonywać autonomicznej wykładni wiążących firmy inwestycyjne i ich

\footnotetext{
${ }^{20}$ M. Tison, op. cit., s. 2632; O. O. Cherednychenko, op. cit., s. 254.

${ }^{21}$ Zob. orzeczenie brytyskiego Sądu Apelacyjnego: Gorham \& others v. British Telecommunications plc, Trustees of the BT Pension Scheme \& Standard Life Assurance Company (2000) 1 WLR 2129 oraz orzeczenia holenderskiego Sądu Najwyższego: De T v. Dexia Bank Nederland NV, HR 5 Jun. 2009, RvdW 2009, 683; Levob Bank NV v. B and GBD, HR 5 June 2009, RvdW 2009, s. 684; Stichting Gedupeerden Spaarconstructie v. Aegon Bank NV, HR 5 June 2009, RvdW 2009, s. 685 - za: O. O. Cherednychenko, op. cit., s. 254 i n.

${ }_{22}$ P. O. Mülbert, The eclipse of contract law in the investment firm-client relationship: the impact of the MiFID on the law of contract from a German perspective, w: G. Ferrrarini, E. Wymeersch (eds.), Investor Protection in Europe. Corporate Law Making, The MiFID and Beyond, Oxford 2007, s. 300 i n.

${ }^{23}$ M. Tison, op. cit., s. 2632; O. O. Cherednychenko, op. cit., s. 254.

${ }^{24}$ P. O. Mülbert, op. cit., s. 300 i n.
} 
klientów umów dotyczących świadczenia usług inwestycyjnych, w tym także wywodzić z tych umów dalej idące obowiązki usługodawcy, niż wynika to z dyrektywy MiFID ${ }^{25}$. Umowy dotyczące świadczenia usług inwestycyjnych moga bowiem ustanawiać dalej idące obowiązki firm inwestycyjnych wobec klientów ${ }^{26}$.

Ochrona inwestora zapewniana przez dyrektywę MiFID oparta jest na założeniu, że instytucje tej dyrektywy będą działały identycznie w każdym kraju członkowskim. Założenie to jest jednak oczywiście kontrfaktyczne - warunki świadczenia usług maklerskich (inwestycyjnych) w poszczególnych państwach członkowskich różnią się pod wieloma względami: systemu prawnego, otoczenia instytucjonalnego, poziomu edukacji inwestorów indywidualnych itd. Instytucje dyrektyw MiFID zapewniają inwestorom należyty poziom bezpieczeństwa w krajach o rozwiniętym rynku kapitałowym. Natomiast w krajach takich jak np. Polska, charakteryzujących się niskim poziomem edukacji inwestorów, ochrona zapewniana inwestorom przez dyrektywy MiFID może okazać się niewystarczajacca ${ }^{27}$. W tych warunkach „lokalne” prawo prywatne może efektywnie, w sposób dopasowany do okoliczności konkretnego przypad$\mathrm{ku}$, uzupełniać ewentualne luki w ochronie inwestora ${ }^{28}$.

Autonomia prawa prywatnego w omawianym zakresie ma jednak ograniczenia. Wydaje się, że dalej idące obowiązki kontraktowe podmiotów świadczących usługi maklerskie nie mogą zupełnie uniemożliwiać realizacji celów dyrektywy MiFID oraz swobody świadczenia usług w ramach wspólnego rynku. Obligatoryjna - tj. wynikajaca z imperatywnych norm prawnych - treść umownych stosunków prawnych w omawianym zakresie nie może sprawiać, że firmy inwestycyjne świadczące usługi inwestycyjne w ramach UE napotykać będą w poszczególnych krajach członkowskich radykalnie odmienny reziim świadczenia tych usług.

\section{Wpływ naruszenia obowiązków wynikających z dyrektywy MiFID na ważność umów o świadczenie usług inwestycyjnych}

W polskiej doktrynie prawa przyjmuje się, że umowa dotycząca świadczenia usług maklerskich zawarta przez podmiot prowadzaccy działalność maklerską bez wymaganego zezwolenia jest nieważna ${ }^{29}$. Stanowisko to koresponduje z utrwaloną już linią orzecznictwa Sądu Najwyższego dotyczącego analogicznego zagadnienia prawnego w ramach innych regulowanych typów działalności gospodarczej oraz wspierającym te orzeczenia stanowiskiem doktryny ${ }^{30}$.

25 Podobnie: A. W. Kawecki, w: D. Busch, D. A. DeMott, op. cit., s. 263.

26 Szerzej na ten temat zob. niżej.

${ }^{27}$ L. Enriques, Conflict of interest in investment services: the price and uncertain impact of MiFID's regulatory framework, w: G. Ferrarini, E. Wymeersch (eds.), Investor Protection..., s. $334 \mathrm{i} \mathrm{n.}$

28 Ibidem.

${ }^{29}$ A. W. Kawecki, w: D. Busch, D. A. DeMott, op. cit., s. 263.

30 Zob. wyrok SN wyrok SN z 19 stycznia 2011 r. (V CSK 173/10, Legalis nr 309869) dotyczący nieważności umowy o pośrednictwo w obrocie nieruchomościami zawartej przez osobę nieuprawnioną do wykonywania zawodu pośrednika; por. także uchwałę SN z 17 lipca 2007 r. 
Podobne stanowisko $\mathrm{w}$ omawianej kwestii zajmuje literatura przedmiotu lub orzecznictwo takich państw jak Włochy, Irlandia oraz - jak się wydaje - Francja (w tym ostatnim kraju zagadnienie to jest wciąż przedmiotem ożywionej dyskusji w literaturze oraz sprzecznych orzeczeń sądów) ${ }^{31}$. Warto jednak zwrócić uwagę na fakt, że w wielu innych krajach UE prezentowane jest odmienne wobec powyższego stanowisko, co świadczy o wysoce dyskusyjnym charakterze problemu ${ }^{32}$. Wskazuje się przede wszystkim, że system udzielania zezwoleń na prowadzenie działalności na rynku finansowym ma chronić przede wszystkim interes publiczny. Tymczasem stosowanie sankcji nieważności czynności prawnej dokonanej przez podmiot nieuprawniony nie zawsze leżeć będzie w interesie klienta, z którym została zawarta umowa ${ }^{33}$.

Uważam, że sankcja nieważności czynności prawnej w przypadku naruszenia przez firmę inwestycyjna publicznoprawnych unormowań dotyczących prowadzenia działalności przez te podmioty powinna być stosowana z dużą ostrożnościa, mając na uwadze okoliczności konkretnego przypadku. W szczególności, wbrew dominującemu poglądowi, stoję na stanowisku, że umowa dotycząca świadczenia usług maklerskich zawarta przez podmiot prowadzący działalność maklerską bez wymaganego zezwolenia jest ważna. Nie przekonuje prezentowany w polskiej doktrynie i orzecznictwie pogląd, zgodnie z którym „skoro ustawodawca reglamentuje określoną działalność, nakładając obowiązek posiadania uprawnień do jej podejmowania, to nie powinien akceptować istnienia ważnych umów zawieranych przez podmioty do ich zawierania nieuprawnione, ani udzielać ochrony roszczeniom wynikającym z tak zawartych umów" ${ }^{34}$. Oznaczałoby to, że te same argumenty aksjologiczne, które przemawiają za licencjonowaniem określonej działalności, przemawiają jednocześnie za wyeliminowaniem z obrotu - poprzez sankcję nieważności czynności prawnej - umów zawartych przez podmioty prowadzące tę działalność bez wymaganej autoryzacji ${ }^{35}$. Tymczasem sa to dwa odmienne problemy. Kwestią odrębna jest nałożenie na podmiot prowadzący działalność bez zezwolenia sankcji administracyjnoprawnych lub nawet karnoprawnych, gdyż sankcja ta „uderza” przede wszystkim w „sprawcę”, który naruszył chroniony przez te normy interes publiczny. Natomiast sankcja nieważności czynności prawnej ingeruje także w interes określonego klienta, który zawarł umowę z firmą inwestycyjna działająca bez zezwolenia i jest podmiotem poniekąd pokrzywdzonym przez to działanie. W odniesieniu do interesu tego klienta, sankcja nieważności czynności prawnej nie zawsze odnosić będzie pozytywne skutki, gdyż często dowie się on o nieprawidłowościach po stronie swojego kontrahenta post factum - po tym, jak przekazał firmie inwestycyjnej środki finansowe, oddał jej instrumen-

(III CZP 69/07, Lex, nr 276909) dotyczący nieważności umowy o zarządzanie nieruchomością. Zob. także: M. Gutowski, Ważność umowy zawartej w zakresie działalności licencjonowanej przez osobę nieposiadajaca wymaganej licencji, „Monitor Prawniczy” 2009, nr 3, s. 168 i n.

${ }^{31}$ D. Busch, D. A. DeMott, op. cit., s. 542.

${ }^{32}$ M. Tison, op. cit., s. 2632; D. Busch, D. A. DeMott, op. cit., s. 542 . W prawie niemieckim zob. szerzej: M. Casper, Ch. Altgen, w: D. Busch, D. A. DeMott, op. cit., s. 131 i n.

${ }_{33}$ M. Tison, op. cit., s. 2632.

${ }^{34}$ M. Gutowski, op. cit., s. 173.

${ }^{35}$ Ibidem. 
ty finansowe do zarządzania, względnie skorzystał z doradztwa inwestycyjnego. W tej sytuacji okazać się może, że roszczenia wynikające z zawartej umowy zdecydowanie lepiej chronią jego interes niż roszczenia z tytułu bezpodstawnego wzbogacenia oraz ewentualne roszczenia z tytułu culpa in contrahendo, które przysługiwałyby klientowi w przypadku nieważności tej umowy ${ }^{36}$.

\section{REŻIM DOTYCZĄCY TZW. ZACHĘT UZYSKIWANYCH PRZEZ ZARZĄDZAJĄCYCH PORTFELEM}

Prawodawca europejski, a w ślad za nim także polski ustanowił publicznoprawne regulacje nakierowane precyzyjnie na problematykę opłat uzyskiwanych lub przekazywanych przez firmę inwestycyjną w związku ze świadczeniem usługi zarządzania portfelem. Przykładowo dotyczy to świadczeń uzyskiwanych od innych firm inwestycyjnych, za pomocą których zarządzający wykonuje zlecenia nabycia lub zbycia instrumentów finansowych w ramach zarządzanego portfela w zamian za kierowanie do nich „strumienia zleceń”. Tego typu zachęty mają tę cechę, że mogą skłaniać zarządców do naruszenia obowiązku lojalności poprzez wykonywanie zleceń w firmach inwestycyjnych, których usługa niekoniecznie jest najkorzystniejsza (np. najtańsza) dla klientów. Regulacje te odnoszą się do wszelkich świadczeń pozostających w związku ze świadczeniem usługi maklerskiej, a nie tylko do świadczeń mających charakter typowych „zachęt"

Paragraf 8 r.t.w.p. w zw. z art. 26 dyrektywy wykonawczej 2006/73/WE (art. 24 ust. 9 MiFID II) wprowadzają ogólne domniemanie, zgodnie z którym przyjęcie lub udzielenie świadczenia pozostającego w związku z wykonywaniem usługi inwestycyjnej (maklerskiej) stanowi naruszenie obowiązku lojalności firmy inwestycyjnej wobec swojego klienta. Analizowane regulacje nie dotyczą więc świadczeń otrzymywanych lub udzielanych przez firmę inwestycyjna, które nie mają jakiegokolwiek związku z usługą maklerską wykonywaną na rzecz klientów ${ }^{38}$. Domniemanie to nie znajduje zastosowania, jeśli firma inwestycyjna działa w oparciu o jeden $\mathrm{z}$ trzech przewidzianych w tych regulacjach wyjątków: Pierwszy z nich dotyczy dość oczywistej sytuacji, gdy świadczenie przekazywane jest na rzecz firmy inwestycyjnej przez klienta (§ 8 ust. 2 pkt 1 r.t.w.p.). Drugi (§ 8 ust. 2 pkt 2 r.t.w.p.) odnosi się do równie naturalnych świadczeń, jakimi są opłaty lub prowizje niezbędne dla świadczenia danej usługi maklerskiej (np. opłaty za usługi depozytowe, opłaty za usługi związane z rozliczaniem lub rozrachunkiem transakcji - zob. art. 24 ust. 9 in fine MiFID II ${ }^{39}$. Trzeci z wyjątków odnosi się do wszystkich pozostałych świad-

\footnotetext{
36 Zob. P. Machnikowski, w: E. Łętowska (red.), System prawa prywatnego. Prawo zobowiazań-część ogólna, t. 5, wyd. 2, Warszawa 2013, s. 524 i n.

${ }^{37}$ CESR Level 3 Recommendations on Inducements under MiFID, Cesr/07-316, May 2007 http://www.esma.europa.eu/system/files/07_316.pdf, s. 4 [dostęp: 12.03.2015].

38 Ibidem, s. 5.

39 Por. M. Kurzajewski, Ustugi maklerskie, Warszawa 2014, s. 184 i n.; por. CESR Level 3 Recommendations on Inducements..., s. 4.
} 
czeń, które zostały uznane przez prawodawcę za dopuszczalne. Świadczenia te muszą spełniać dwie cechy: po pierwsze, informacja o tych świadczeniach obejmująca ich istotę, wysokość lub sposób jej ustalania została przekazana klientowi przed zawarciem umowy o świadczenie danej usługi maklerskiej ${ }^{40}$; po drugie, sa one przyjmowane albo przekazywane w celu poprawienia jakości usługi maklerskiej świadczonej przez firmę inwestycyjną na rzecz klienta (§ 8 ust. 2 pkt 3 r.t.w.p. $)^{41}$.

Na gruncie dyrektywy MiFID II w odniesieniu do zarządzania portfelem instrumentów finansowych prawodawca europejskie zdecydował się na jeszcze dalej idące obostrzenia majace na celu ochronę inwestorów korzystających z usług maklerskich (zob. motyw 74 MiFID II). Firma inwestycyjna co do zasady nie może przyjmować jakichkolwiek świadczeń lub korzyści od osób trzecich, a w szczególności od emitentów instrumentów finansowych lub dostawców produktów finansowych. Jedynym wyjątkiem od tej zasady są drobne korzyści niepieniężne, które mogą zwiększyć jakość usługi świadczonej klientowi i które nie wpływają negatywnie na przestrzeganie przez firmę inwestycyjna jej obowiązku działania zgodnie z najlepiej pojętym interesem klienta, pod warunkiem że zostały wyraźnie ujawnione (art. 24 ust. 7(b) oraz art. 28 MiFID II).

Prawodawca europejski zakłada także, że świadczenia otrzymane przez firmę inwestycyjną wykonująca usługi zarządzania portfelem z naruszeniem regulacji ograniczających dopuszczalność ich przyjmowania podlegają przekazaniu na rzecz klientów (zob. motyw 74 MiFID II). Zgodnie z art. 24 ust. 9 MiFID II, zgodnie z którym w stosownych przypadkach firma inwestycyjna informuje również klienta o mechanizmach przekazywania klientowi opłat, prowizji, korzyści pieniężnych lub niepieniężnych otrzymanych w związu ze świadczeniem usługi inwestycyjnej lub dodatkowej ${ }^{42}$.

Odpowiedź na pytanie, czy w świetle aktualnie obowiązującego prawa polskiego na firmie inwestycyjnej świadczącej usługę inwestycyjną na rzecz klienta ciąży kontraktowy obowiązek zwrotu „zachęt” na rzecz klienta, może budzić kontrowersje. Wynikaja one $\mathrm{z}$ rozbieżności $\mathrm{w}$ zakresie wykładni art. 740 zd. 2 k.c., z którego wynika obowiąek zleceniobiorcy do zwrotu zleceniodawcy wszystkiego, „co przy wykonaniu zlecenia dla niego uzyskał”. W starszej literaturze przedmiotu przyjmowano, że „tego rodzaju świadczenia należy wydać dajaccemu zlecenie”, gdyż to ,zapobiega w pewnym stopniu niewłaściwemu działaniu przyjmującego zlecenie”43. „Przyjmujący zlecenie nie może działać w interesie osób trzecich. Nie wolno mu przyjmować od innych osób podarków, gratyfikacji i innych podobnych świadczeń”44.

${ }^{40}$ Co do szczegółowości tej informacji zob. także $§ 8$ ust. 3 r.t.w.p.

${ }^{41}$ Por. M. Kurzajewski, op. cit., s. 198 i n.

${ }^{42} \mathrm{~W}$ prawie niemieckim por. M. Casper, Ch. Altgen, w: D. Busch, D. A. DeMott, op. cit., s. 110; P. O. Mülbert, Auswirkungen der art. 19 ff MiFID auf das Zivilrecht am Beispiel von Vertriebsvergütungen im Effektengeschäft der Kreditinstitute, ZHR nr. 172, 2008, s. 170 i n.

${ }^{43}$ A. Szpunar, w: Z. Radwański (red.), System prawa cywilnego, t. 3, cz. 2: Prawo zobowiazań - część szczegółowa, Wrocław 1976, s. 398 i n.

${ }^{44}$ A. Szpunar, w: Z. Radwański (red.), op. cit., s. 398. 
Stanowisko to nie rozróżnia wystarczająco precyzyjnie dwóch płaszczyzn analizowanego zagadnienia, a mianowicie: po pierwsze, ewentualnego naruszenia obowiązku lojalności wobec zleceniodawcy wynikającego z przyjęcia przez zleceniobiorcę „zachęty” od osoby trzeciej; a po drugie, obowiązku zwrotu na podstawie art. 740 zd. 2 k.c. Trafnie więc nowsza literatura przedmiotu uznaje, że zleceniobiorca nie ma obowiązku przekazania na rzecz zleceniodawcy świadczeń uzyskanych wprawdzie ze względu na wykonywanie zlecenia, ale dla siebie, a nie dla zleceniodawcy ${ }^{45}$. Zupełnie odrębna kwestia jest natomiast to, że przyjęcie świadczenia od osoby trzeciej najczęściej stawia zleceniobiorcę w sytuacji konfliktu interesów, który z kolei może prowadzić do naruszenia obowiązku lojalności zleceniobiorcy wobec zleceniodawcy, a więc niewykonywania usługi wyłącznie w interesie zleceniodawcy ${ }^{46}$. Wydaje się jednak, że transpozycja do polskiego systemu prawnego postanowień dyrektywy MiFID II dotyczących zachęt wiązać się będzie z koniecznością zmian legislacyjnych w tym zakresie, a w szczególności jednoznacznego wprowadzenia obowiązku zwrotu bezprawnie pobranych przez firmę inwestycyjną świadczeń związanych ze świadczeniem usługi maklerskiej.

\section{ODPOWIEDZIALNOŚĆ CYWILNA ZARZĄDZAJĄCEGO}

Nienależyte wykonanie zobowiązania do zarządzania portfelem instrumentów finansowych naraża usługodawcę na odpowiedzialność odszkodowawczą na podstawie art. 471 k.c. Warto jednak zauważyć, że zdarzenie to stanowić może jednocześnie naruszenie publicznoprawnych regulacji dotyczacych tej usługi. Naruszenie publicznoprawnych unormowań dotyczących sposobu świadczenia usługi zarządzania portfelem skutkować może odpowiedzialnością odszkodowawczą na podstawie art. 415 k.c. ${ }^{47}$

Dopuszczenie do spadku wartości portfela instrumentów finansowych oddanego w zarządzanie nie jest jednak tożsame z naruszeniem zobowiązania przez podmiot zarządzajaccy. Co do zasady zobowiązanie firmy inwestycyjnej do zarządzania portfelem jest bowiem zobowiązaniem starannego działania, a nie zobowiązaniem rezultatu. Firma nie gwarantuje wyników finansowych oferowanej usługi. Spadku wartości portfela nie można także automatycznie utożsamiać ze szkodą inwestora, która powinna podlegać naprawieniu. Spadek wartości portfela może być bowiem spowodowany czynnikami będacymi poza sferą wpływu podmiotu zarządzającego tym portfelem ${ }^{48}-\mathrm{np}$. uwarunkowaniami makroekonomicznymi.

${ }^{45}$ Ibidem. Tak też: K. Kopaczyńska-Pieczniak, w: A. Kidyba (red.), Kodeks cywilny. Komentarz, t. 3, wyd. 2, Warszawa 2014, s. 755-756.

${ }^{46} \mathrm{Na}$ temat tego obowiązku por. A. Szpunar, w: Z. Radwański (red.), op. cit., s. 396 i n.

${ }^{47}$ M. Casper, Ch. Altgen, w: D. Busch, D. A. DeMott (eds.), op. cit., s. 107; A. W. Kawecki, w: D. Busch, D. A. DeMott (eds.), op. cit., s. 266.

${ }^{48}$ Ch. Benicke, Wertpapiervermögensverwaltung, Tübingen 2006, s. 832 i n. 
Do typowych przykładów naruszenia zobowiązania przez podmiot zarządzający portfelem należy ${ }^{49}$ : zarządzanie portfelem sprzecznie z określonymi przez strony celami inwestycyjnymi klienta albo wbrew ustalonej polityce zarządzania tym portfelem; nabycie do portfela instrumentów finansowych bez wymaganej w danym wypadku analizy fundamentalnej; nienależyte doradztwo zarządzającego przy ustalaniu z klientem polityki zarządzania portfelem; świadczenie usługi nieodpowiedniej dla danego klienta, czy też nadmierna częstotliwość transakcji (tzw. churning) ${ }^{50}$.

Naruszenie przez firmę inwestycyjną niektórych przepisów o charakterze publicznoprawnym implementujaccych dyrektyw MiFID do prawa polskiego dotyczących sposobu świadczenia usług inwestycyjnych może stać się podstawa jej odpowiedzialności odszkodowawczej wobec inwestorów na podstawie art. 415 i n. k.c. ${ }^{51}$ Bezpośrednim celem tych przepisów jest bowiem ochrona interesów inwestorów. Przykładem takiego naruszenia może być wykonywanie usługi zarządzania portfelem bez uzyskania informacji o kliencie, które świadczyłyby, że usługi te są odpowiednie dla tego klienta (§ 16 ust. 5 r.t.w.p.), względnie naruszenie obowiązków informacyjnych firmy inwestycyjnej przed zawarciem umowy o świadczenie tej usługi (art. 19 ust. 3 dyrektywy MiFID I oraz $§ 13$ r.t.w.p.), a w szczególności w przypadku niepoinformowania klienta o ryzykach związanych $\mathrm{z}$ inwestowaniem $\mathrm{w}$ dany rodzaj instrumentów finansowych.

Co do zasady szkodę będącą wynikiem naruszenia obowiązków przez zarządzającego należy obliczać jako różnicę pomiędzy rzeczywistą wartością portfela instrumentów finansowych a jego hipotetyczną wartością w sytuacji, gdyby nie doszło do naruszenia tych obowiązków ${ }^{52}$. Podlegająca naprawieniu szkodą może być zarówno strata (np. spadek wartości nabytego instrumentu finansowego), jak i utracone korzyści (np. wzrost wartości instrumentów finansowych, w które środki zostałyby zainwestowane) ${ }^{53}$.

Podstawowym zagadnieniem, które w tym kontekście z reguły rozważa się w literaturze, jest zakres stosunków majątkowych poszkodowanego, który należy analizować dla określenia wysokości poniesionej szkody przez klienta firmy inwestycyjnej. W szczególności poszukuje się odpowiedzi na pytanie, czy dla określenia rzeczywistej wartości majątku poszkodowanego po zdarzeniu wywołującym szkodę należy brać pod uwagę całkowitą wartość zarządzanego portfela, a więc wszystkie wchodzące w jego skład instrumenty finansowe oraz środki pieniężne, czy też ściśle określone instrumenty finansowe lub określona transakcję ich dotycząca, która stanowiła naruszenie zobowiązania zarządzającego $^{54}$. Odpowiedź na to pytanie w praktyce sprowadza się do ustalenia, czy

49 Ibidem, s. 813.

50 Ibidem, s. 812 .

${ }^{51}$ Tak też: A. W. Kawecki, w: D. Busch, D. A. DeMott (eds.), op. cit., s. 266

52 Zob. ogólnie: Z. Radwański, A. Olejniczak, Zobowiazania-część ogólna, wyd. 11, Warszawa 2014, s. 93; M. Kaliński, Szkoda na mieniu i jej naprawienie, Warszawa 2014, s. 188 i n.

${ }^{53}$ M. Casper, Ch. Altgen, w: D. Busch, D. A. DeMott (eds.), op. cit., s. 126; por. K. Zacharzewski, Szkoda giełdowa i jej naprawienie, Toruń 2015, s. 408.

${ }^{54}$ K. Zacharzewski, op. cit., s. 422 i n. W literaturze niemieckiej zob. np. M. Casper, Ch. Altgen, w: D. Busch, D. A. DeMott (eds.), op. cit., s. 127; Ch. Benicke, op. cit., s. 837 i n. 
ujemne następstwa zdarzenia powodującego szkodę, dotyczące jednych instrumentów finansowych, mogą być kompensowane z korzyściami wynikającymi $\mathrm{z}$ innych instrumentów finansowych znajdujących się w portfelu ${ }^{55}$.

Analizujac ten problem z punktu widzenia prawa polskiego, przyjać należy, że podczas ustalania rzeczywistej wartości majątku poszkodowanego należy brać po uwagę całokształt stosunków majątkowych poszkodowanego po zdarzeniu wywołującym szkodę, a nie jedynie bezpośrednie następstwa tego zdarzenia ${ }^{56}$. Natomiast analizowany problem dotyczy raczej dopuszczalności zaliczania uzyskanych przez klienta korzyści na poczet szkody (compensatio lucri cum damno). Odpowiedź na to pytanie zależy wprost od natury zdarzenia wywołującego szkodę, a konkretniej od rodzaju naruszonego obowiązku zarządzającego. Jeżeli bowiem naruszony został obowiązek odnoszacy się do całego portfela instrumentów finansowych, to dla obliczenia wielkości poniesionej przez klienta szkody należy brać pod uwagę realną wartość całego portfela, na którą wpływają także ewentualne korzyści (compensatio lucri cum damno). wynikające z nienależytego zarządzania tym portfelem. Inaczej należałoby oceniać sytuację, w której naruszenie obowiązku zarządzającego polegało na nabyciu określonego typu instrumentów finansowych - np. akcji spółki X, nabytych bez należytej analizy fundamentalnej. W tej sytuacji dla obliczenia rzeczywistej wartości majątku poszkodowanego nie można na poczet szkody wynikłej z nabycia akcji spółki X zaliczyć korzyści wynikłych z nabycia przez zarządzającego do portfela tegoż klienta akcji spółek Y i Z. W tej sytuacji brakuje więc tożsamości zdarzenia, którego następstwem miałaby być równocześnie szkoda, jak i uzyskana korzyśćc ${ }^{7}$.

Największą trudność przy obliczaniu wielkości szkody sprawia określenie hipotetycznej wartości zarządzanego portfela w sytuacji, gdyby podmiot zarządzający nie naruszył swoich obowiązków. Specyficzną cechą odpowiedzialności za naruszenie zobowiązania przez zarządzającego portfelem instrumentów finansowych notowanych w zorganizowanym obrocie jest to, że stworzenie modelu (projekcji) hipotetycznej wartości zarządzanego portfela w sytuacji niezaistnienia zdarzenia szkodzącego nie jest konieczne wyłącznie do obliczenia ewentualnych utraconych korzyści ${ }^{58}$, ale także straty klienta firmy inwestycyjnej (damnum emergens) ${ }^{59}$.

Przy tworzeniu modelu hipotetycznego kształtowania się wartości prawidłowo zarządzanego portfela należy przede wszystkim brać pod uwagę zachowanie się „zdrowej” części portfela ${ }^{60}$. Tego typu ekstrapolacja kształtowania się wartości prawidłowo zarządzanej części portfela na część niepoprawnie zarządzaną jest oczywiście możliwe wyłącznie w sytuacji, gdy po pierwsze, chociaż część portfela była prawidłowo zarządzana, a po drugie, prawidłowo

\footnotetext{
${ }_{55}$ Ch. Benicke, op. cit., s. 837 i n.

56 Z. Radwański, A. Olejniczak, op. cit., s. 93.

${ }^{57}$ Ibidem, s. 94.

58 Ibidem, s. 93.

59 Ch. Benicke, op. cit., s. 865.

60 Ibidem.
} 
zarządzana część portfela posiada strukturę, która jest w określony sposób zbliżona do nieprawidłowej struktury całości portfela ${ }^{61}$.

Powyższa operacja intelektualna będzie jednak nieadekwatna, jeżeli prawidłowa część portfela, zgodnie z umowa, posiada strukturę, która nie może być $\mathrm{w}$ żaden sposób miarodajna dla struktury nieprawidłowej części portfela. W tych warunkach model kształtowania się hipotetycznej wartości nieprawidłowej części portfela, w przypadku należytego nią zarządzania, należy budować w oparciu o inne obiektywne mierniki. Należy przede wszystkim uwzględnić treść umowy o zarządzanie, a w szczególności ustaloną politykę zarządzania portfelem odnoszącą się do tej części. Jeżeli precyzuje ona wymogi dotyczące struktury tej części portfela, należy je oczywiście wziąć pod uwagę, gdyż zawężają one krąg potencjalnych mierników oddziałujących na strukturę portfela. W grę może natomiast wchodzić zachowanie się wartości jednostek uczestnictwa grupy najpopularniejszych funduszy inwestycyjnych o podobnej polityce zarządzania co analizowana część tego portfela ${ }^{62}$. W przypadku dostępności danych dopuszczalne jest uwzględnianie także wyników osiaganych przez inne podmioty zarządzające portfelem instrumentów finansowych o podobnej strukturze ${ }^{63}$. Budujac model hipotetycznego kształtowania się wartości portfela, zasady doświadczenia życiowego nakazują uznać za uprawnione domniemanie faktyczne, że zarządzajaccy - bez istotnej przyczyny - nie pozostawiałby dłuższy czas bezproduktywnie środków finansowych klienta ${ }^{64}$.

Obowiązek zarządzającego sprowadzający się do naprawienia szkody powstałej wskutek naruszenia zobowiązania wynikającego z umowy o zarzadzanie portfelem instrumentów finansowych może podlegać odpowiedniemu zmniejszeniu w przypadku przyczynienia się poszkodowanego stosownie do art. 362 k.c. Najbardziej oczywistym przypadkiem przyczynienia się poszkodowanego do szkody w analizowanych okolicznościach jest podanie przez poszkodowanego zarządzającemu nieprawdziwych lub niepełnych informacji na temat swojej sytuacji majątkowej i osobistej, co może powodować nieprawidłową rekomendację w zakresie ustalania polityki zarządzania portfelem instrumentów finansowych ${ }^{65}$. Braku reakcji klienta na niezgodne $\mathrm{z}$ umowa wykonywanie usługi (np. prowadzenie nadmiernie ryzykownej polityki zarządzania portfelem) i niezgłaszanie w związku z tym pretensji lub uwag skierowanych do zarządzającego nie można co do zasady poczytywać jako przyczynienie się poszkodowanego do szkody ${ }^{66}$. Klient korzystajacy z usługi zarządzania portfelem nie ma obowiązku bieżącego monitorowania sposobu świadczenia tej usługi i składania reklamacji co do naruszenia obowiązków przez zarządzającego ${ }^{67}$.

${ }^{61}$ Ibidem; zob. także: M. Casper, Ch. Altgen, w: D. Busch, D. A. DeMott (red.), op. cit., s. 127.

${ }^{62}$ Ch. Benicke, op. cit., s. 846; M. Casper, Ch. Altgen, w: D. Busch, D. A. DeMott (eds.), op. cit., s. 126.

${ }^{63}$ M. Casper, Ch. Altgen, w: D. Busch, D. A. DeMott (eds.), op. cit., s. 127.

${ }^{64}$ Inaczej: M. Casper, Ch. Altgen, w: D. Busch, D. A. DeMott (eds.), op. cit., s. 127.

${ }^{65}$ Ch. Benicke, op. cit., s. 882.

${ }^{66}$ Ibidem, s. 882 i n.

${ }^{67}$ Co do wyjątków od tej zasady zob. Ch. Benicke, op. cit., s. 890 i n.; M. Casper, Ch. Altgen, w: D. Busch, D. A. DeMott (eds.), Ibidem, s. 128 i n. 


\section{PODSUMOWANIE}

Znaczenie wynikających z dyrektywy MiFID I regulacji publicznoprawnych dotyczących świadczenia usług maklerskich jest szczególnie istotne w krajach Europy Środkowej i Wschodniej z uwagi na stosunkowo małe doświadczenie sądownictwa oraz doktryny w rozstrzyganiu sporów i zawiłych problemów prawnych powstajacych na tym tle. Przewidziany w dyrektywach MiFID publicznoprawny obowiązek lojalności firmy inwestycyjnej wobec swoich klientów (art. 19 ust. 1 dyrektywy MiFID I oraz art. 24 ust. 1 dyrektywy MiFID II) wprowadza do systemu prawnego oraz dyskursu prawniczego kategorię mało znana w tych systemach prawnych. Chodzi tutaj o wypracowaną w anglosaskich systemach prawnych instytucję obowiązków powierniczych (lojalnościowych - fiduciary duties), które umożliwiaja w sposób elastyczny ograniczanie działania powiernika dysponującego kompetencjami do dyskrecjonalnego kształtowania sytuacji majątkowej powierzającego ${ }^{68}$.

W pewnym sensie wprowadzony przez dyrektywy MiFID obowiązek lojalności firmy inwestycyjnej wobec swojego klienta, na rzecz którego świadczy ona usługi maklerskie, pełni ważną rolę edukacyjną i transformującą kulturę prawną tych krajów. Można więc zakładać, że w odróżnieniu od niektórych dojrzałych rynków kapitałowych - np. rynku niemieckiego - gdzie dyrektywie MiFID I przypisywano efekt potencjalnie łagodzący nadmierna surowość prawa prywatnego oraz znaczna aktywność sądów w zakresie ochrony inwestorów ${ }^{69}$, w Polsce i zapewne innych krajach tzw. nowej Europy będzie raczej pobudzał organy nadzoru, jak i sądy cywilne do większej aktywności w tym zakresie.

dr hab. Tomasz Sójka

Profesor Uniwersytetu im. Adama Mickiewicza w Poznaniu tsojka@amu.edu.pl

\section{THE CIVIL LIABILITY OF ASSET MANAGERS}

\section{Sum mary}

This paper focuses on the civil liability of asset managers under Polish law. Following the transformation of the economic system and the development of the capital market in Poland, the importance of asset management has been gradually increasing, though it remains disproportionally lower when compared to the role of collective asset management in the form of investment funds. The chief purpose of both MiFID directives is to harmonise the rules applicable to investment firms providing brokerage services in Europe, and to protect the interests of investors who use brokerage services. Although the civil liability of investment firms offering brokerage services is part of what is broadly construed as investor protection, the regulations on this matter have been left to the Member States' discretion. There is no doubt that discrepancies between Member States in this respect diminish the harmonising effect of both directives. This paper aims to determine the basic rules of civil liability of asset managers in Polish law, and present suggestions for the most common problems in this field.

${ }^{68}$ Zob. K. Pistor, Ch. Xu, Fiduciary duty in transitional civil law jurisdictions lessons from the incomplete law theory, w: C. J. Milhaupt (ed.), Global Markets, Domestic Institutions: Corporate Law and Governance in a New Era of Cross-Border Deals, New York 2003, s. 78 i n.

${ }^{69}$ N. Moloney, Liability of asset managers: a comment, „Capital Markets Law Journal” 7(4), 2012, s. 416. 
Artykuł „Odpowiedzialność cywilna zarządzającego portfelem instrumentów finansowych” autorstwa Tomasza Sójki jest wynikiem projektu badawczego finansowanego ze środków Narodowego Centrum Nauki na podstawie decyzji nr DEC-2013/09/B/HS5/00289. 